in obese patients with gallstones. $\mathrm{Br} \operatorname{Med} J$ 1978; i: 1509-12.

4 Carey M C. Critical tables for calculating the cholesterol saturation of native bile. J Lipid Res 1978; 19: 945-55.

5 MacMillan $R$ W, Schullinger J N, Santulli T V. Cholelithiasis in childhood. Am J Surg 1974; 127: 689-92.

6 Stiehl A, Czygan P, Kommerell B, Weis H J, Holtermüller K G. Ursodeoxycholic acid versus chenodeoxycholic acid: comparison of their effects on bile acid and bile lipid composition in patients with cholesterol gallstones. Gastroenterology 1978; 75: 1016-20.
7 Reddy B S, Wynder E L. Metabolic epidemiology of colon cancer. Fecal bile acids and neutral sterols in colon cancer patients, and patients with adenomatous polyps. Cancer 1977; 39: 2533-9.

8 Linos D A, O'Fallon W M, Beart R W, Jr, Beard C M, Dockerty $M$ B, Kurland L T. Cholecystectomy and carcinoma of the colon. Lancet 1981; ii : 379-81.

Correspondence to Dr M Podda, Istituto di Clinica Medica III, 15 Via Pace, 20122 Milano, Italy.

Received 16 July 1982

\title{
Prenatal exclusion of severe combined immunodeficiency
}

\author{
R J LEVINSKY, D C LINCH, C L BEVERLY, AND C RODECK \\ Institute of Child Health and The Hospital for Sick Children, University College Hospital Medical School, and \\ King's College Hospital Medical School, London
}

\begin{abstract}
SUMMARY By analysing leucocyte subpopulations with monoclonal antisera, we have shown that the diagnosis of severe combined immunodeficiency can be made soon after birth. The technique of staining has been adapted for small blood samples, and normal ranges of leucocyte subpopulations have been established for fetal blood taken from midtrimester pregnancies. Using this information, we gave prenatal advice to an at risk family and predicted that the pregnancy would be normal; this was confirmed after birth. This technique should allow prenatal diagnosis for severe combined immunodeficiency, especially if the phenotype of a previously affected child is known.
\end{abstract}

Severe combined immunodeficiency (SCID) is a heterogeneous syndrome inherited either as an $\mathrm{X}$-linked or an autosomal recessive disorder. Affected children lack both cell-mediated and humoral immunity; they present with repeated viral, bacterial, or fungal infections, have protracted diarrhoea, and failure to thrive. ${ }^{1}$ Unless treated by bone marrow transplants the children generally die within the first year of life.

Most patients have an absolute deficiency of T-cell numbers with numbers of B-cells being absent, very low, or very high. Within families a similar pattern of T- and B-cell numbers is observed in affected individuals (personal experience of six families with more than one affected child). In $20 \%$ of the autosomal recessive type, the disease is caused by a deficiency of adenosine deaminase, and in such families prenatal diagnosis demonstrates lack of the enzyme in amniotic cells. ${ }^{2}$ Prenatal diagnosis is not yet available for the remaining cases. However, the development of monoclonal antibodies which distinguish leucocyte populations, and in particular T-cell subsets, has enabled normal ranges to be established in healthy children and adults (unpublished). Similarly, the diagnosis of various forms of immunodeficiency can be made by analysing lymphocyte phenotypes. We have recently developed a method for analysing the phenotype of leucocytes from very small samples of blood using monoclonal antibodies and a fluorescent activated cell sorter. Using this technique, normal ranges for leucocyte populations have been established in the second trimester of pregnancy on fetal blood samples $(100-500 \mu \mathrm{l})$ obtained at fetoscopy for diagnosis of thalassaemia and haemophilia. ${ }^{3}$ It is therefore possible, if one knows the phenotype of a previously affected sibling, to offer prenatal advice to an at risk family during a second pregnancy.

\section{Methods}

Staining mononuclear cells. Venous blood specimens were obtained from 2 children with SCID in the first 2 days of life, and from 5 others below the age of 6 months. Mononuclear cells were obtained by Ficoll-Triosil centrifugation and after washing were stained with monoclonal mouse antisera (aliquots of cells at $2 \times 10^{5} / \mathrm{ml}$ ) to human leucocyte subpopulations. The following antisera were used: (1) UCHT1 which recognises all mature T-cells. ${ }^{4}(2)$ Leu $3 a$ which recognises helper/inducer T-cells. ${ }^{5}$ (3) Leu $2 \mathrm{a}$ which recognises suppressor/cytotoxic T-cells. ${ }^{5}$ (4) DA2 which recognises a non-polymorphic determinant of HLA Dr antigen. ${ }^{6}(5)$ OKM1 which recognises cells of the monocytic series, some granulocytes, and cells with natural killer activity. ${ }^{7}$ (6) Anti Hle-1 which reacts with all peripheral blood leucocytes. ${ }^{4}$

B-cells were recognised by staining surface immunoglobulin-bearing cells with fluorescent-labelled rabbit or sheep antihuman immunoglobulin (Wellcome Laboratories).

The cells stained with monoclonal antisera were 
washed three times and then with a second layer of fluorescent-labelled sheep antimouse immunoglobulin. After extensive washing, the percentages of cells stained with fluorescent-labelled antibodies were enumerated in a fluorescent-activated cell sorter.

Whole blood modification for fetal samples. Because less than $500 \mu 1$ blood could be obtained from the mid-trimester fetus at fetoscopy, it was not possible to fractionate mononuclear cells by Ficoll-Triosil centrifugation. A leucocyte-rich fraction was obtained by allowing red cells to sediment with hydroxyethyl starch for 20 minutes (equal volumes added to heparinised blood sample). The nucleated cells remained in the supernatant and these were washed in the wells of a microtitre plate. The cells were stained at a concentration of $2 \cdot 5-5 \times 10^{4}$ nucleated cells $/ \mathrm{ml}$ in a similar manner to that described above. Just before analysis in the fluorescentactivated cell sorter, the residual red cells were lysed using dilute Zapoglobin (Coulter Electronics Ltd) ( 2 drops in $10 \mathrm{ml}$ Isoton buffer, $150 \mu l$ of this to $200 \mu \mathrm{l}$ cell suspension). Fetal blood samples were obtained at fetoscopy for diagnosis of thalassaemia and haemophilia and a normal range of leucocyte populations between 14 and 20 weeks' gestation was derived.

\section{Case history}

A boy (Case 7), the first child of unrelated parents presented at 6 months with a prolonged chest infection resistant to conventional antibiotics. Lung biopsy revealed the diagnosis of Pneumocystis carinii infection and he recovered after treatment with high dose co-trimoxazole and pentamidine. The clinical impression of SCID was confirmed by very low $\mathrm{T}$-cell percentages $(3 \%$ enumerated by sheep red blood cell rosette formation), very high B-cell percentages $(29 \%)$, failure of his mononuclear cells to proliferate in response to lectin;-such as phytohaemagglutinin and conconavlin $\mathbf{A}$-absent mixed lymphocyte response, and virtually absent serum IgG, IgA, and IgM. Surprisingly, he remained well for the next year on weekly immunoglobulin injections, but thereafter he developed lung infections due to Pseudomonas aeruginosa infection and died shortly after his second birthday. For the second pregnancy, fetal blood was obtained at 18 weeks' gestation and analysed as described.

\section{Results}

The phenotype of the lymphocyte populations of the 7 children with SCID is shown in Table 1 and compared with the normal ranges for children of this age established in our laboratory. The pattern of Tand B-cell antigen expression is heterogeneous, but is constant if tested repeatedly for each child. Furthermore, within families, if one child has SCID with high B-cell numbers, further affected children show the same pattern (personal experience).

In Table 2 the results of leucocyte subpopulations found in normal fetal blood (range of 11 samples

Table 1 Phenotype of the lymphocyte populations of 7 children with severe combined immunodeficiency

\begin{tabular}{|c|c|c|c|c|c|c|}
\hline Cases & $\begin{array}{l}U C H T I \\
(\text { all } T \text {-cells })\end{array}$ & $\begin{array}{l}\text { Leu } 3 a \\
\text { (helper T-cells) }\end{array}$ & $\begin{array}{l}\text { Leu } 2 a \\
\text { (suppressor/cytotoxic } \\
T \text {-cells) }\end{array}$ & $\begin{array}{l}\text { SIg } \\
(B-\text { cells })\end{array}$ & $\begin{array}{l}D A 2 \\
(H L A D r)\end{array}$ & $\begin{array}{l}\text { OKMI } \\
\text { (monocytes) }\end{array}$ \\
\hline $\begin{array}{l}1 \\
2 \\
3 \\
4 \\
5 \\
6\end{array}$ & $\begin{array}{l}6 \\
7 \\
4 \\
0 \\
1 \\
1\end{array}$ & $\begin{array}{l}2 \\
0 \\
1 \\
0 \\
0 \\
1\end{array}$ & $\begin{array}{l}2 \\
3 \\
1 \\
0 \\
0 \\
0\end{array}$ & $\begin{array}{r}2 \\
68 \\
1 \\
0 \\
0 \\
76\end{array}$ & $\begin{array}{l}32 \\
88 \\
41 \\
29 \\
21 \\
27\end{array}$ & $\begin{array}{l}31 \\
21 \\
36 \\
32 \\
26 \\
22\end{array}$ \\
\hline 7 & 10 & 0 & 7 & 29 & 54 & 30 \\
\hline Control range & $53-77$ & $40-52$ & $19-28$ & $8-18$ & $5-17$ & $18-32$ \\
\hline
\end{tabular}

Results expressed as a percentage of mononuclear cells isolated by Ficoll-Hypaque centrifugation.

Table 2 Results of leucocyte subpopulations in normal fetal blood

\begin{tabular}{|c|c|c|c|c|c|}
\hline & $\begin{array}{l}\text { UCHTI } \\
(\text { all } T \text {-cells })\end{array}$ & $\begin{array}{l}\text { Leu } 3 a \\
\text { (helper } T \text {-cells) }\end{array}$ & $\begin{array}{l}\text { Leu } 2 a \\
\text { (suppressor/cytotoxic) } \\
T \text {-cells) }\end{array}$ & $\begin{array}{l}S I g \\
(B-c e l l s)\end{array}$ & $\begin{array}{l}D A 2 \\
(H L A D r)\end{array}$ \\
\hline $\begin{array}{l}\text { *Fetus at } 18 \text { weeks } \\
\text { †Affected brother with SCID } \\
\text { *Baby retested after birth }\end{array}$ & $\begin{array}{l}57 \\
10 \\
38\end{array}$ & $\begin{array}{r}40 \\
0 \\
35\end{array}$ & $\begin{array}{r}18 \\
7 \\
10\end{array}$ & $\begin{array}{r}7 \\
29 \\
4\end{array}$ & $\begin{array}{r}5 \\
54 \\
20\end{array}$ \\
\hline $\begin{array}{l}\text { Control range of } 11+\text { fetal blood } \\
\text { samples gestation } 14-20 \text { weeks }\end{array}$ & $33-51$ & $21-44$ & $6-18$ & 4-34 & $6-37$ \\
\hline
\end{tabular}

*Expressed as percentage of whole blood leucocytes (HLe-1 positive cells); †expressed as percentage of mononuclear cells only. 
taken at gestations from 14 to 20 weeks) is shown. The results are those of whole blood analysis (expressed as a \% of Hle-1 positive cells) in comparison with the higher values obtained for mononuclear cell preparations. The results of the 18-week fetal blood sample from the at risk pregnancy is shown to be normal. The pregnancy was continued, and on testing at birth the baby was confirmed to be normal by repeated lymphocyte phenotype analysis and by normal lymphocyte response in mixed lymphocyte culture and to phytohaemagglutinin. The child is well aged 16 months.

\section{Discussion}

We have shown that SCID can be diagnosed soon after birth by phenotype analysis of lymphocyte populations using monoclonal antisera. Similarly, using these antisera and the fluorescent-activated cell sorter we have developed a technique of staining small numbers of cells, thereby being able to provide a leucocyte profile on very small blood samples. We have established a normal range of these leucocyte subpopulations for fetal blood from 14 to 20 weeks' gestation and have used this information to provide prenatal advice for a family at risk of having further children affected with SCID. In this case the fetal blood analysis was normal and this was confirmed by the birth of a normal child. As yet we have not made a prenatal diagnosis of SCID and recommended that the pregnancy be terminated, but recently this diagnosis was established in France, although by using only two monoclonal markers. ${ }^{8}$ Our technique allows a greater range of antibodies to be used for a similar sized blood sample and should increase confidence in making such a diagnosis, especially if the phenotype of a previously affected sibling is known.

Monoclonal antibodies to leucocyte subpopulations now provide the means of offering prenatal diagnosis for SCID in cases other than those due to adenosine deaminase deficiency. The risks of an abortion occurring after fetal blood sampling are $<3 \%$ and most families would find that acceptable. The only variety not amenable to diagnosis is if the child has normal percentages of T- and B-cells but the cells do not function properly. Fortunately, this is the rarest variety of SCID.

\section{Addendum}

Since this report was accepted we have screened a second at risk fetus at 19 weeks' gestation. The male fetus was shown to have SCID with high B-cell numbers (same pattern as affected first child) and was aborted. The diagnosis was confirmed by the absence of lymphocyte response to phytohaemagglutinin and at necropsy of the fetus by an absence of the T-cell areas in the thymus and spleen.

\section{C L is a Wellcome Research Fellow.}

This study was supported by grants from the Leukaemia Research Fund, the Medical Research Council, and National Fund for Research into Crippling Diseases.

\section{References}

1 Amman A J, Hong R. Disorders of the T cell system. In: Stiehm E R, Fulginiti $V A$, eds. Immunological disorders in infants and children, second edition. Philadelphia: Saunders, 1980: 286-348.

2 Hirschhorn R. Clinical delineation of adenosine deaminase deficiency. In: Elliott K, Whelan J, eds. Enzyme defects and dysfunction. Ciba Foundation Symposium No 68, New Series. Amsterdam: Elsevier, 1979: 35-49.

3 Linch D C, Beverley P C L, Levinsky R J, Rodeck C H. Phenotypic analysis of foetal blood leucocytes; potential for antenatal diagnosis of immunodeficiency disorders. Prenatal Diagnosis 1982; 2 : 211-8.

4 Beverley P C L. Production and use of monoclonal antibodies in transplant immunology. In: Proceedings of the Eleventh International Course on Transplant and Clinical Immunology. Amsterdam: Excerpta Medica, 1980: 87-94.

5 Evans R L, Wall D W, Piatsoucas G D, et al. Thymus dependent membrane antigens in man: inhibition of cell mediated lympholysis by monoclonal antibodies to $\mathrm{TH}_{2}$ antigen. Proc Natl Acad Sci USA 1981 ; 78 : 544-8.

${ }^{6}$ Brodsky F M, Parham P, Barnstable C J, Crumpton M J, Bodmer W F. Monoclonal antibodies for analysis of the HLA system. Immunol Rev 1979; 47: 3-61.

7 Breard J, Reinherz E L, Kung P C, Goldstein G, Schossman S F. A monoclonal antibody reactive with human peripheral blood monocytes. J Immunol 1980; 124: 1943-8.

8 Durandy A, Griscelli C, Dumez Y, et al. Letter: Antenatal diagnosis of severe combined immunodeficiency from fetal cord blood. Lancet 1982; i: 852-3.

Correspondence to $\operatorname{Dr} R \mathbf{J}$ Levinsky, Department of Immunology, Institute of Child Health, 30 Guilford Street, London WCIN $1 \mathrm{EH}$.

Received 5 August 1982 